\title{
Characterization of a Strain of Turnip vein-clearing virus Causing Red Ringspot of Penstemon
}

Benham E. Lockhart, Department of Plant Pathology, Axelina S. Swenson, College of Biological Sciences, Neil E. Olszewski, Department of Plant Biological Sciences, and Peter Voth, Plant Biological Sciences Graduate Group, University of Minnesota, St. Paul 55108

\begin{abstract}
Lockhart, B. E., Swenson, A. S., Olszewski, N. E., and Voth, P. 2008. Characterization of a strain of Turnip vein-clearing virus causing red ringspot of penstemon. Plant Dis. 92:725-729.

A disease of penstemon (Penstemon digitalis) occurring in commercial nurseries in Minnesota in 2004 to 2006 and characterized by red foliar ringspots, leaf deformation, and plant stunting was found to be caused by a strain of Turnip vein-clearing virus (TVCV) that was named Penstemon ringspot virus (PenRSV). This is the first report of a viral disease of penstemon. The genome organization of PenRSV was similar to that of the crucifer-infecting tobamoviruses. The nucleotide sequence of PenRSV was almost identical (99\%) to that of TVCV, but the two viruses differed importantly in host range and symptoms induced. The only sequence difference between PenRSV and TVCV occurred at the $3^{\prime}$ end of open reading frame I, where the amino acid sequence FRDSNL in TVCV is replaced by FRGQQL in PenRSV. The experimental host range of PenRSV included species in the families Brassicaceae (Cruciferae), Cactaceae, Cucurbitaceae, Leguminosae, Malvaceae, and Solanaceae. This virus poses a potential threat to commercial nursery and bedding plant production because of its wide host range and because it will escape detection by immunoenzymatic screening procedures for tobamoviruses based on use of antibodies to Tobacco mosaic virus (TMV).
\end{abstract}

Penstemon, or beard-tongue (Penstemon spp.), is a herbaceous perennial that is grown as a landscape plant and for cut flowers. Long popular in Europe, this perennial ornamental has been increasing in popularity in North America, as evidenced by the establishment of the American Penstemon Society and the selection of Penstemon digitalis 'Husker Red' as perennial plant of the year in 1996 by the Perennial Plant Association (http://www.perennial plant.org). During 2004 to 2006, plants of Husker Red were observed with disease symptoms in several commercial nurseries in Minnesota. Symptoms consisted of stunting, leaf deformation, and red ringspotting of the foliage (Fig. 1). Virus-like particles characteristic of tobamoviruses (Fig. 2) were observed by transmission electron microscopy (TEM) in negatively stained partially purified extracts (2) of symptomatic Husker Red leaf tissue, but were not observed in similar preparations from asymptomatic Husker Red plants grown from seed. The study described in this report was conducted to establish the

Corresponding author: B. E. Lockhart

E-mail: lockh002@umn.edu

Genomic information has been deposited in GenBank under accession number NC_008295.

Accepted for publication 18 December 2007.

doi:10.1094/PDIS-92-5-0725

(C) 2008 The American Phytopathological Society role of the tobamo-like virus in the etiology of red ringspot disease of penstemon and to provide information on the biological and other properties of the causal agent. This is the first report of a naturally occurring viral infection in penstemon.

\section{MATERIALS AND METHODS}

Virus source, transmission, and host range. An isolate of the putative Tobamovirus sp. associated with disease symptoms in Husker Red penstemon was obtained by three serial single-lesion passages in Nicotiana alata and then was propagated in $N$. benthamiana, which served as virus source for all subsequent experiments. Virus transmission tests were done by mechanical inoculation of Carborundum-dusted leaves of indicator test plants using crude sap extracts of infected $N$. benthamiana prepared in $100 \mathrm{mM}$ sodium-potassium phosphate buffer, $\mathrm{pH}$ 7.5, containing $0.25 \%$ ( $\mathrm{vol} / \mathrm{vol})$ 2-mercaptoethanol. Inoculated plants were maintained at 22 to $27^{\circ} \mathrm{C}$ for 1 to 12 months post inoculation. They were observed for symptom development and tested for presence of virus by double-antibody sandwich enzyme-linked immunosorbent assay (DAS-ELISA) and by immunosorbent electron microscopy (ISEM) using partially purified leaf tissue extracts (2) as described below. A common strain of Tobacco mosaic virus (TMV) (ATCC PV135) and a Minnesota isolate of Ribgrass mosaic virus (RMV) from Plantago major were used as internal controls for capsid protein $(\mathrm{CP})$ size measurement.

Virion purification, characterization, and serology. Virions were partially purified from infected $N$. benthamiana leaf tissue extracted in $100 \mathrm{mM}$ phosphate, $\mathrm{pH}$ $7.0,0.5 \%$ ( vol $/ \mathrm{vol})$ 2-mercaptoethanol, clarified with chloroform:n-butanol (1:1 $\mathrm{vol} / \mathrm{vol})$, and concentrated by polyethylene glycol (PEG) precipitation (7). Further purification was done by isopycnic density-gradient centrifugation in $33 \%$ (wt/wt) $\mathrm{CsCl}$ at $15^{\circ} \mathrm{C}$ for $30 \mathrm{~h}$ at $180,000 g_{\text {max }}$. Virus concentration was estimated using an assumed extinction coefficient of 3.0. Partially purified and purified preparations were examined by TEM following negative staining with $2 \%(\mathrm{wt} / \mathrm{vol})$ sodium phosphotungstate (PTA), $\mathrm{pH} 7.0$, containing bacitracin at $250 \mathrm{mg} / \mathrm{ml}$. Microscope magnification was calibrated using the crystal lattice spacing of stained catalase crystals (20). Genomic RNA was extracted from purified virion suspensions as described (16). Size estimate of the genomic RNA under denaturing conditions was

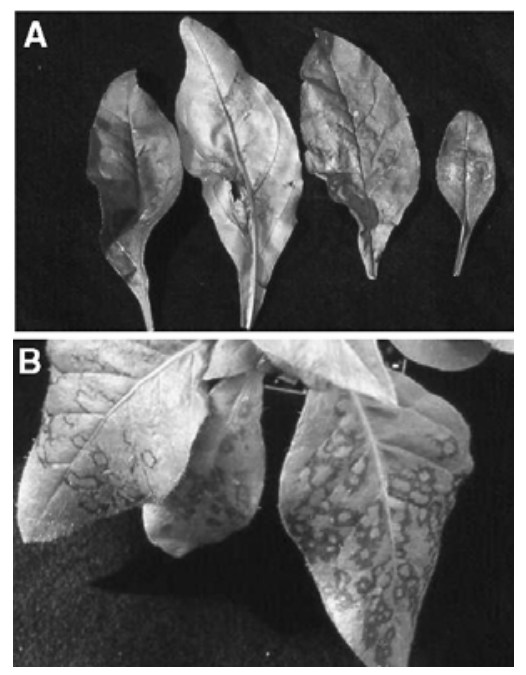

Fig. 1. Symptoms induced by Penstemon ringspot virus (PenRSV) in penstemon and petunia. A, Symptoms caused by penstemon ringspot virus infection in naturally and experimentally infected Penstemon digitalis 'Husker Red.' At left, healthy Husker Red leaf; center two leaves, red ringspot symptoms in naturally infected Husker Red; at right, systemic ringspot symptoms in Husker Red following mechanical inoculation with a PenRSV single lesion isolate propagated in Nicotiana benthamiana. B, Systemic black ringspot symptoms induced in petunia by PenRSV. 
determined by electrophoresis in native $1.5 \%$ Tris-acetate-EDTA (TAE) agarose gels using Superload Denaturing Gel Loading Buffer (Viagen, Austin, TX). The molecular mass of virion capsid subunits was estimated by discontinuous sodium dodecyl sulfate polyacrylamide gel electrophoresis (SDS-PAGE; 9) using a Benchmark 10- to 220-kDa protein ladder (Invitrogen, San Diego, CA) as size markers. An antiserum to the virus was prepared by immunizing a New Zealand White rabbit. Subcutaneous injections of purified virions emulsified in Titermax Gold adjuvant (Sigma-Aldrich, St. Louis) were administered at days $0(5 \mathrm{mg})$ and 14 (2.5 $\mathrm{mg}$ ). Blood samples were collected starting at day 42. Serological tests were performed by ISEM (12) and DAS-ELISA (4).

Reverse-transcription polymerase chain reaction, cloning, and sequence analysis. After initial host range tests had revealed that Penstemon ringspot virus (PenRSV) was biologically similar to Turnip vein-clearing virus (TVCV), primers based on the available complete genomic TVCV sequence (GenBank acc. no. NC_001873) were used to amplify overlapping regions covering approximately
$98 \%(6,191$ nucleotides [nt]) of the PenRSV genome. Additional primers, based on the resulting PenRSV genomic sequence, were used to fill gaps not covered by the TVCV primers. The designation, nucleotide sequence, and position of these primers are listed in Table 1. Amplicons were generated by reversetranscription polymerase chain reaction (RT-PCR) using the Ready-Bead Kit (Amersham), according to manufacturer's instructions. Total RNA extracted from PenRSV-infected $N$. benthamiana leaf tissue preserved in RNALater (Ambion, Inc.) using an RNeasy kit (Qiagen) was used as template for RT-PCR. Amplicons generated by RT-PCR were cloned using a TopoTA kit (Invitrogen). For each amplicon, both strands were sequenced from three to five clones. Sequencing was done at the Biomedical Genomics Center, University of Minnesota, St. Paul. Nucleotide and amino acid sequence analyses were done using Sequencher (Gene Codes Corporation, Ann Arbor, MI).

\section{RESULTS}

Virus transmission, host range, and symptoms. A single-lesion isolate of PenRSV isolated from diseased Husker
Red penstemon and propagated in N. benthamiana was transmitted by mechanical inoculation to healthy Husker Red plants grown from seed and induced the original disease symptoms in these plants (Fig. 1A, right). No virus-like particles other than those of PenRSV were detected by TEM or ISEM in any of these plants. From this, it was concluded that PenRSV was the sole causal agent of the red ringspot disease occurring in Husker Red penstemon, and that the use of the proposed name "Penstemon ringspot virus" was appropriate. The experimental host range of PenRSV (Table 2) consisted of 37 plant species in 16 families, and included a number of ornamentals that are of importance to commercial horticulture. The host range included species in all five plant families (Brassicaceae [Cruciferae], Cactaceae, Cucurbitaceae, Malvaceae, and Solanaceae) susceptible to infection by the currently recognized or proposed Tobamovirus subgroups based on host plant family specificity $(1,5,8,10,13,15,18)$. PenRSV infection in a number of susceptible host plant plants was not associated with symptom expression (Table 2). However, in the majority of these cases, PenRSV virion titer, as assessed by TEM and ISEM using
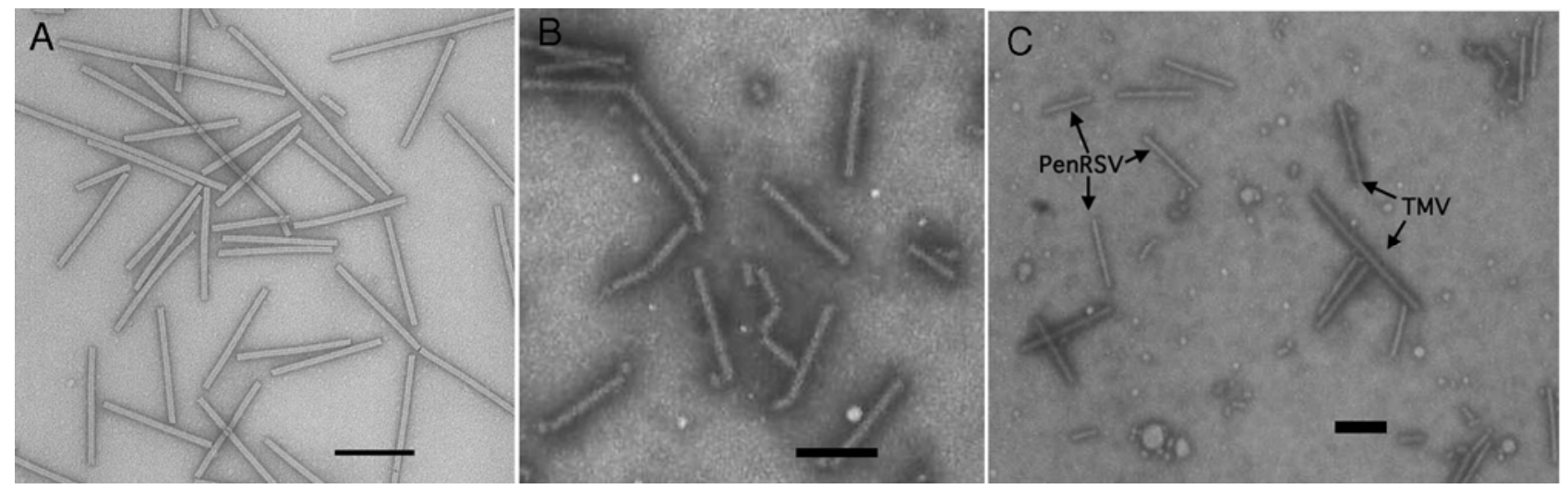

Fig. 2. Morphology of Penstemon ringspot virus (PenRSV) virions and immunosorbent electron microscopy (ISEM) with antibodies to Tobacco mosaic virus (TMV). A, Virions of PenRSV purified by isopycnic density-gradient centrifugation in $\mathrm{CsCl}$ were negatively stained with $2 \%$ (wt/vol) sodium phosphotungstate (PTA), pH 7.0, containing bacitracin at $250 \mu \mathrm{g} / \mu \mathrm{l}$. Scale bar represents $200 \mathrm{~nm}$. B, Virions of PenRSV were trapped and decorated with homologous antibodies. Negative staining and scale bar as in A. C, Mixture of PenRSV and TMV virions (indicated by labeled arrows) trapped by respective homologous antibodies and incubated subsequently with antiserum to TMV. Figure illustrates specific decoration of TMV particles and lack of decoration of those of PenRSV. Negative staining and scale bar as in A and B.

Table 1. Names and locations of oligonucleotide primers used for obtaining the nucleotide sequence of Penstemon ringspot virus (PenRSV) genome by reverse-transcription polymerase chain reaction amplification

\begin{tabular}{|c|c|c|c|c|}
\hline Primer pair ${ }^{a}$ & Location $(n t)^{b}$ & Amplicon size $(n t)^{b}$ & Forward primer & Reverse primer \\
\hline TVCV2F/TVCV2R & $305-1,288$ & 983 & ttc aaa ggg gat tac gtt cac & $\operatorname{tgc} c t t$ gtc tgt gtc cca ttc aga \\
\hline TVCV3F/TVCV3R & $1,265-2,257$ & 992 & tct gaa tgg gac aca gac aag gca & aac caa ctt gtg gtt ggc gtc ttc \\
\hline TVCV4F/TVCV4R & $2,001-3,103$ & 1,102 & agg gaa cta tga tgt ctg ggg tgt & cgg agt tga tgt caa gcg cac aat \\
\hline TVCV1f/TVCV1R & $3,174-3,699$ & 525 & att aca ccg ttg tgt tgg acc cga & ccc ttg tca tgg tca ttt cgt tcg t \\
\hline TVCV5F/TVCV5R & $3,595-4,446$ & 851 & aca tga atg cgc cgg att tga cag & aga gtt tgg cct cga agt tcc aca \\
\hline TVCV7F/TVCV7R & $4,818-5,471$ & 653 & aag gaa gag atc ttg cga agg ct & acg aat cag gac cgg cgt att tct \\
\hline TVCV8F/TVCV8R & $4,825-5,930$ & 1,105 & gat ctt gcc gaa ggc tct aac & tgt ttg gta cga ttg cga caa cgc \\
\hline TVCV9F/TVCV9R & $5,558-5,930$ & 372 & aat gct taa cca gtg cat gtc ggc & agc ctc gaa ctc tgc cet att cat \\
\hline PenRSV1F/PenRSV1R & $2,744-3,285$ & 541 & aat tcg aga gtc gcc aac ttt ccg & aag ggc gga ata ctg cat cga tct \\
\hline PenRSV2F/PenRSV2R & $955-1,554$ & 599 & att gga act cet ccg cet tet tgt & tat gga cga tgc gtg gca cta caa \\
\hline
\end{tabular}

a Primers designated TVCV are based on the Turnip vein-clearing virus (TVCV) genomic sequence (NC_001873) and primers designated PenRSV are based on the PenRSV genomic sequence (NC_008295).

$\mathrm{b} \mathrm{nt}=$ Nucleotides 
partially purified leaf tissue extracts, was similar to that of symptomatic indicator plants. One exception was radish, which was infected subliminally and in which virions of PenRSV could be detected only by ISEM using partially purified extracts. This possibly may explain why radish was reported previously as a nonhost of a crucifer-infecting Tobamovirus sp. (10).

Virion purification, electron microscopy, characterization, and serology. Negatively stained purified virion suspensions obtained by isopycnic density gradient centrifugation contained 300-by-18-nm rigid rod-shaped particles typical of tobamoviruses (Fig. 2A). A single species of single-stranded RNA approximately $6.3 \mathrm{~kb}$ in size (Fig. 3A) was detected by ethidium bromide staining in RNA extracted from purified virions and, from the same virion preparations, a single polypeptide of approximately $17 \mathrm{kDa}$ was detected by SDSPAGE (Fig. 3B). The observed relative mobility (10) of the PenRSV polypeptide was similar to that of RMV and slightly higher than that of TMV (Fig. 3A). Similar differences in the electrophoretic migration profiles of the TMV and TVCV CP polypeptides has been reported previously (10). However, it should be noted that CP size may vary among different isolates of RMV (8). Antiserum prepared against purified PenRSV antigen reacted strongly with homologous antigen in both DAS-ELISA (data not shown) and ISEM (Fig. 2B), but very poorly or not at all with TMV antigen in the same assays (Fig. 2C). Similar results (Fig. 2C) were obtained in reciprocal tests using antiserum to TMV.

RT-PCR, cloning, and sequence analysis. By analogy to the complete nucleotide sequence of TVCV $(6,311 \mathrm{nt}$, NC_001873), approximately $98 \%$ of the PenRSV genome (6,191 nt, NC_008295) was obtained by RT-PCR using the primers listed in Table 1. Nucleotide and amino acid sequence identities between the replicase (RdRP), movement protein (MP), and coat protein $(\mathrm{CP})$ domains of PenRSV and the corresponding domains of the other member of the crucifer-infecting Tobamovirus subgroup are listed in Table 3. The sequence data indicated that PenRSV has 98 to $100 \%$ sequence identity to TVCV but is distinct from TMV-CR, Oilseed rape mosaic virus (ORMV), and RMV. This observation is in agreement with those of previous studies based on phylogenetic analyses of the $\mathrm{CP}$ sequences of crucifer-infecting Tobamovirus spp. $(8,11,17,21)$.

\section{DISCUSSION}

Tobamovirus spp. have been divided into one of three subgroups based on genome organization $(3,6)$. Viruses in subgroup I have their origin of assembly (OA) in the MP domain, whereas subgroup 2 contains viruses whose OA occurs in the CP domain. Subgroup 1 and 2 Tobamovi- rus spp. also are characterized by an overlap between replicase and MP coding regions and no overlap between MP and CP $(3,6)$. Tobamovirus spp. assigned to sub-

group 3 also have their $\mathrm{OA}$ in the $\mathrm{CP}$ domain, but differ from subgroup 2 members in having a 77-nt overlap between the MP and $\mathrm{CP}$ domains. Tobamovirus spp. also

Table 2. Experimental host range of Penstemon ringspot virus (PenRSV) based on mechanical inoculation of indicator plants

\begin{tabular}{|c|c|}
\hline Family, indicator plant species & Infection/symptoms ${ }^{\mathrm{a}}$ \\
\hline \multicolumn{2}{|l|}{ Amaranthaceae } \\
\hline Amaranthus retroflexus (pigweed) & $-1-$ \\
\hline Gomphrena globosa (Globe amaranth) & NLL/- \\
\hline \multicolumn{2}{|l|}{ Araliaceae } \\
\hline Schefflera aboricola (Schefflera) & NSP/NSP \\
\hline \multicolumn{2}{|l|}{ Brassicaceae } \\
\hline Arabidopsis thaliana & NS/NS \\
\hline Brassica juncea (Indian mustard) & NS/NS \\
\hline B. oleracea (broccoli) & NS/NS \\
\hline B. oleracea (cauliflower) & NS/NS \\
\hline B. oleracea var. capitata (cabbage) & NS/NS \\
\hline B. perkinensis (Chinese cabbage) & NS/NS \\
\hline B. rapa (turnip) & $\mathrm{NS} / \mathrm{VC}$ \\
\hline Crambe abyssinica (crambe) & NS/VC, MOS \\
\hline Raphanus sativus (radish) & NS/NS \\
\hline \multicolumn{2}{|l|}{ Cactaceae } \\
\hline Opuntia 'Angel Wings' & NSP/NSP \\
\hline Schlumbergera sp.(Christmas cactus) & $-1-$ \\
\hline \multicolumn{2}{|l|}{ Caryophyllaceae } \\
\hline Antirrhinum majus (snapdragon) & MOS/MOS \\
\hline Lychnis alba & NS/NS \\
\hline Penstemon digitalis (beard tongue) & RSP/RSP \\
\hline Stellaria media (chickweed) & NS/NS \\
\hline \multicolumn{2}{|l|}{ Chenopodiaceae } \\
\hline Chenopodium quinoa & $-1-$ \\
\hline \multicolumn{2}{|l|}{ Compositae } \\
\hline Zinnia elegans (Zinnia) & MOS/MOS \\
\hline \multicolumn{2}{|l|}{ Crassulaceae } \\
\hline Kalanochoë blossfeldiana (kalanochoë) & CLL/NS \\
\hline \multicolumn{2}{|l|}{ Cucurbitaceae } \\
\hline Cucumis sativus (cucumber) & CLL/- \\
\hline \multicolumn{2}{|l|}{ Gesneriaceae } \\
\hline Saintpaulia ionatha (African violet) & NS/NS \\
\hline \multicolumn{2}{|l|}{ Labiatae } \\
\hline Ajuga reptans (bugleweed) & $-1-$ \\
\hline Lamium maculatum (deadnettle) & NS/NS \\
\hline \multicolumn{2}{|l|}{ Liliaceae } \\
\hline Hosta fortuneii (Hosta) & $-1-$ \\
\hline \multicolumn{2}{|l|}{ Leguminosae } \\
\hline Phaseolus vulgaris (bean) & NLL/- \\
\hline Pisum sativum (pea) & CLL/- \\
\hline Vigna unguiculata (cowpea) & $-1-$ \\
\hline \multicolumn{2}{|l|}{ Malvaceae } \\
\hline Abelmoschus esculenta (okra) & $-1-$ \\
\hline Abutilon theophrastii (velvetleaf) & NS/NS \\
\hline Peperomiaceae & \\
\hline Peperomia caperata (peperomia) & NS/NS \\
\hline Plantaginaceae & \\
\hline Plantago major (common plantain) & NLL/NS \\
\hline Primulaceae & \\
\hline Cyclamen persicum (cyclamen) & NS/MOS \\
\hline Saxifragaceae & \\
\hline Hydrangea macrophylla (florists' hydrangea) & $-1-$ \\
\hline Solanaceae & \\
\hline Capsicum аппиит (bell pepper) & NLL/- \\
\hline C. frutescens (hot pepper) & NLL/- \\
\hline Datura stramonium (jimsonweed) & NLL/- \\
\hline Lycopersicon estulentum (tomato) & $-1-$ \\
\hline Nicotiana alata & NLL/- \\
\hline N. benthamiana & RSP/RSP \\
\hline N. clevelandii & RSP/RSP \\
\hline N. debneyi & RSP/RSP \\
\hline N. glutinosa & NLL/- \\
\hline N. occidentalis & RSP/RSP \\
\hline N. rustica & RSP/RSP \\
\hline N. tabacum & RSP/RSP \\
\hline Petunia $\times$ hybrida (petunia) & NLL/RSP \\
\hline
\end{tabular}

${ }^{a}$ Infection (local or systemic) symptoms: $-=$ no infection, NS = symptomless infection, CLL = chlorotic local lesions, $\mathrm{NLL}=$ necrotic local lesions, $\mathrm{MOS}=$ mosaic, $\mathrm{RSP}=$ ringspots, and $\mathrm{VC}=$ vein-clearing. 
have been divided into six proposed subgroups based on host range specificity and serological relatedness $(1,3,8,13,15,17$, 18,21). These six proposed subgroups consist of viruses with host ranges specific to the families Brassicacae (Cruciferae), Cactaceae, Cucurbitaceae, Leguminosae, Malvaceae, and Solanaceae, respectively. These two Tobamovirus classification schemes are mutually compatible and are supported by numerous phylogenetic analyses showing that Tobamovirus spp. fall into clusters that are correlated with genome organization, host range specificity, and serological affinity $(1,3,8,13,15,17$, 18,21).

The subgroup 3 or crucifer-infecting Tobamovirus spp. have been divided further into two subgroups based on host range and MP size differences (21). The first of these subgroups consists of TVCV (10) and Russian TMV-Cr (5), which do not infect either petunia or tomato. The second crucifer-infecting Tobamovirus subgroup consists of RMV, ORMV (=Youcai mosaic virus [YoMV]; 3), and the Wasabi strain of TMV (TMV-W; 14), which infect both petunia and tomato and have slightly smaller MP open reading frames because of a longer gap between the replicase and MP genes (17). This further subgrouping of crucifer-infecting Tobamovirus spp. is

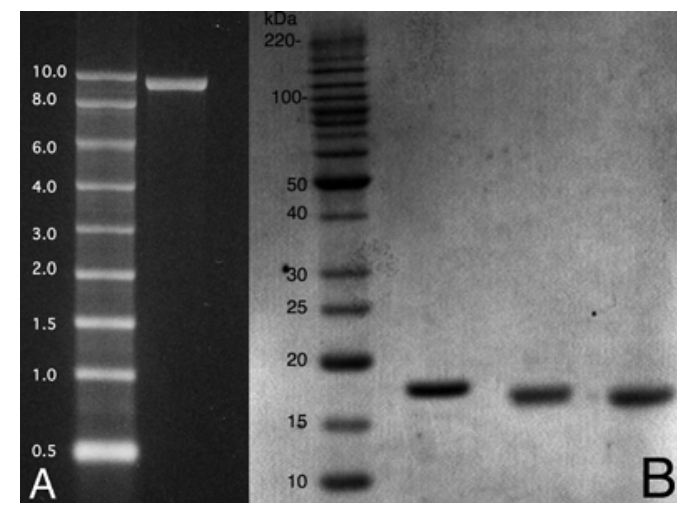

Fig. 3. Determination of number and size of nucleic acid and protein components associated with purified Penstemon ringspot virus (PenRSV) virions. A, Electrophoretic migration profile of PenRSV genomic RNA under denaturing conditions in 1.5\% agarose in Tris-Borate-EDTA. Sizes (nucleotides) of the nine-component single-stranded RNA reference ladder are listed on the left of the figure. B, Estimation of molecular mass of PenRSV capsid polypeptide by sodium dodecyl sulfate polyacrylamide gel electrophoresis. Lane 1, 10- to 220-kDa protein ladder; lane 2, Tobacco mosaic virus; lane 3, PenRSV; lane 4, Ribgrass mosaic virus (Minnesota isolate).

Table 3. Nucleotide (nt) and amino acid (aa) sequence identity between Penstemon ringspot virus (PenRSV) and other crucifer-infecting Tobamovirus spp.

\begin{tabular}{|c|c|c|c|c|c|c|}
\hline \multirow[b]{3}{*}{ Virus $^{b}$} & \multicolumn{6}{|c|}{ Coding region $(\%)^{\mathbf{a}}$} \\
\hline & \multicolumn{2}{|c|}{ RdRP } & \multicolumn{2}{|c|}{ MP } & \multicolumn{2}{|c|}{$\mathbf{C P}$} \\
\hline & nt & aa & nt & aa & nt & aa \\
\hline TVCV & 98 & 98 & 99 & 100 & 99 & 99 \\
\hline TMV-Cr & 92 & 86 & 94 & 93 & 94 & 91 \\
\hline ORMV & 80 & 88 & 81 & 82 & 85 & 89 \\
\hline RMV & 80 & 87 & 81 & 81 & 89 & 93 \\
\hline
\end{tabular}

${ }^{a} \mathrm{RdRP}=$ replicase, $\mathrm{MP}=$ movement protein, and $\mathrm{CP}=$ coat protein domains of PenRSV.

${ }^{\mathrm{b}} \mathrm{TVCV}=$ Turnip vein-clearing virus $\left(\mathrm{NC} \_001873\right), \mathrm{TMV}-\mathrm{Cr}=$ Tobacco mosaic virus-Cruciferae $\left(\mathrm{AB} \_003936\right), \mathrm{ORMV}=$ Oilseed rape mosaic virus $\left(\mathrm{NC} \_004422\right)$, and $\mathrm{RMV}=$ Ribgrass mosaic virus (NC_002792). cies were detected in virions of PenRSV (Fig. 3A), and the very high level of nucleotide sequence identity between PenRSV and TVCV in all three coding regions (Table 3) appears to exclude the possibility that PenRSV represents a recombinant between TVCV and a member of another Tobamovirus subgroup. In this regard, Zhu et al. (21) have remarked previously that, because distinct biological (i.e., host range) differences between crucifer-infecting Tobamovirus spp. are not correlated with significant nucleotide sequence differences, "....small differences in sequence must account for the observed differences in host range and symptoms." This observation appears to be borne out in the cases of PenRSV and TVCV, which share $99 \%$ nucleotide sequence homology yet differ significantly in host range. The largest sequence difference between these two biologically distinct Tobamovirus spp. is the replacement of the amino acid sequence FRDSNL (1,116 to 1,121) in TVCV by the sequence FRGQQL in PenRSV at the $3^{\prime}$ end of the RdRP. Therefore, it is possible that this may represent one specific example of a minor change in sequence that was predicted to be correlated with differences in biological behavior (21). A similar possibility was proposed by Shimamoto et al. (17), who suggested that observed differences in the ability of crucifer-infecting Tobamovirus spp. to infect petunia and tomato systemically might depend on specific differences in sequence in the replicase or MP genes. Targeted substitutions or deletions within this FRGQQL motif may provide empirical evidence to test the hypothesis that these relatively minor sequence differences are correlated with differences in host range.

For the commercial horticulture industry, PenSRV poses a potential threat for two reasons. First, PenRSV is capable of infecting a wide range of commercially important species (e.g., petunia), including several which either have been reported to be only subliminally infected by TMV (e.g., African violet; 19) or have not been reported previously as hosts of Tobamovirus spp. (e.g., schefflera and kalanchoë). The second is that PenRSV will not be detected in routine ELISA-based assays used in the industry for screening plants for Tobamovirus infection. For these two reasons, it would seem prudent to reevaluate currently used protocols for screening perennial ornamentals for Tobamovirus infection.

\section{ACKNOWLEDGMENTS}

This work was supported by Minnesota Agricultural Experiment Station (M.A.E.S.) research project 22-79H directed by B. E. Lockhart.

\section{LITERATURE CITED}

1. 1.Adkins, S., Kamenova, I., Achor, D., and Lewandowski, D. 2003. Biological and molecular characterization of a novel tobamovirus with a unique host range. Plant 
Dis. 87:1190-1196.

2. Agrawal, Y. S., Pant, R. P., Lockhart, B. E. L., Srivastava, M., Chakraborty, N. K., and Varma, A. 1996. Association of a badnavirus with citrus mosaic disease in India. Plant Dis. 80:590590.

3. Aguilar, I., Sanchez, F., Martin, A., MartinezHerrera, D., and Ponz, F. 1996. Nucleotide sequence of Chinese rape mosaic virus (oilseed rape mosaic virus), a crucifer tobamovirus infectious on Arabidopsis thaliana. Plant Mol. Biol. 30:191-197.

4. Clark, M. F., and Adams, A. N. 1977. Characteristics of the microplate method of enzymelinked immunosorbent assay for the detection of plant viruses. J. Gen. Virol. 34:475-483.

5. Dorokhov, Yu. L., Ivanov, P. A., Novikov, V. K., Agranovsky, A. A., Morozov, S. Yu., Efimov, V. A., Casper, R., and Atabekov, J. G. 1994. Complete nucleotide sequence and genome organization of a tobamovirus infecting cruciferae plants. FEBS Lett. 350:5-8.

6. Fukuda, M., Meshi, T., Okada, Y., and Takebe, I. 1981. Correlation between particle multiplicity and location on virion RNA of the assembly initiation site for viruses of the tobacco mosaic virus group. Proc. Natl. Acad. Sci. USA 78:4231-4235

7. Gooding, G. V., Jr., and Hebert, T. T. 1967. A simple technique for purification of tobacco mosaic virus in large quantities. Phytopathology $57: 1285$

8. Heinz, C., Lesemann, D.-E., Ilmberger, N.,
Willingmann, P., and Adam, G. 2006. The phylogenetic structure of the cluster of Tobamovirus species serologically related to Ribgrass mosaic virus (RMV) and the sequence of streptocarpus flower break virus. Arch. Virol. 151:763-774.

9. Laemmli, U. K. 1970. Cleavage of structural proteins during assembly of head of bacteriophage T4. Nature (Lond.) 227:680-685

10. Lartey, R. T., Hartson, S. D., Pennington, R. E., Sherwood, J. L., and Melcher, U. 1992. Occurrence of a vein-clearing tobamovirus in turnip. Plant Dis. 77:21-24.

11. Li, Z-Y. 1983. Crucifer strain $\mathrm{f}$ tobacco mosaic virus isolated from garlic. Mem. Fac. Agric. Hokkaido Univ. 13:542-549.

12. Lockhart, B. E. L., Autrey, J. J-C., and Comstock, J. C. 1996. Partial purification and serology of sugarcane mild mosaic virus, a mealybug-transmitted closterolike virus. Phytopathology 82:691-695.

13. Min, B. E., Chung, B. N., Kin, M. J., Ha, J. H., Lee, B. Y., and Ryu K. H. 2006. Cactus mild mottle virus is a new cactus-infecting tobamovirus. Arch. Virol. 151:13-21.

14. Oshima, N., Ohashi, Y., and Umekawa, M. 1974. Studies on some strains of tobacco mosaic virus pathogenic to crucifer plants. 2. Host range Ann. Phytopathol. Soc. Jpn. 40:243-251.

15. Ryu, K. H., Min, B. E., Choi, G. S., Choi, S. H., Kwon, S. B., Noh, G. M., Yoon, J. Y., Choi, Y. M., Jang, S. H., Lee, G. P., Cho, K. H., and Park, W. M. 2000. Zucchini green mottle mo- saic virus is a new tobamovirus; comparison of its coat protein gene with that of kyuri green mottle mosaic virus. Arch. Virol. 145:23252333.

16. Scagliusi, S. M., and Lockhart, B. E. L. 2000. Transmission, characterization and serology of a luteovirus associated with yellow leaf syndrome of sugarcane. Phytopathology 90:120124.

17. Shimamoto, I., Sonoda, S., Vazquez, P., Minaka, N., and Nishiguchi, M. 1998. Nucleotide sequence analysis of the $3^{\prime}$ terminal region of a wasabi strain of crucifer tobamovirus genomic RNS: subgrouping of crucifer tobamoviruses. Arch. Virol. 143:1801-1813.

18. Srinivasan, K. G., Narendrakumar, R., and Wong, S. M. 2002. Hibiscus virus $S$ is a new subgroup II tobamovirus: evidence from its unique coat protein and movement protein sequences. Arch. Virol. 147:1585-1598.

19. Sulzinski, M. A., Jurkonie, D. D., and Adonizio, C. S. 1994. Tobacco mosaic virus subliminal infection of African violet. J. Am. Hortic. Sci. 119:702-705.

20. Wrigley, N. G. 1968. The lattice spacing of crystalline catalyse as an internal standard of length in electron microscopy. J. Ultrastruct. Res. 24:454-464.

21. Zhu, H., Hong, J., Ye, R., Chen, J., Yu, S., and Adams, M. J. 2001. Sequence analysis shows that Ribgrass mosaic virus shanghai isolate (RMV-Sh) is closely related to Youcai mosaic virus. Arch. Virol. 146:1231-1238. 